\title{
Zaurgarritasun ibilbideetan balantzaka
}

\author{
Aiala Elorrieta Agirre \\ Ekonomia Aplikatua I Departamentua, Ekonomia eta Enpresa Zientzien Fakultatea, \\ Euskal Herriko Unibertsitatea UPV/EHU \\ <aia.elorrieta.agirre@gmail.com>
}

\begin{abstract}
Artikulu honen bidez doktorego tesian eskuratu diren emaitza nagusiak eman nahi dira aditzera. Ikerlanean zehar, gizarte bazterkeriaren bideetara gerturatu gara, zaurgarritasun istorioak nola perfilatzen diren aztertu asmoz. Zehazki, Dirusarrerak Bermatzeko Errenta (DBE) jasotzen duten hamazortzi pertsonari burututako sakoneko elkarrizketetan oinarritu gara eta kontakizun hauei heldu diegu zaurgarritasunak har ditzakeen itxura anitzak behatzeko. DBE prestazioa zaurgarritasun ibilbide horietan ongizatearen euskarri sendoa izanik ere, egoera hauskorrak gainditzeko nahikoa sostengu ez dela uste dugu. Ikerketaren izenburuan bertan hipotesi nagusi honen arrastoren bat ematen da aditzera: "Zaurgarritasun bideetan balantzaka. Diru-sarrerak Bermatzeko Errentaren argi-ilunak". Izan ere, adierazpide honek ezegonkortasun zantzu bat iradokitzen digu; prestazioa bazterkeriaren aurkako borrokan hankamotz geratzen denaren ideia. Ikerketaren emaitza nagusi gisa, bazterkeria faktoreek eta esparruek elkarren artean kateatzeko dauzkaten era amaigabeen artean, bi eredu nagusi nabarmendu dira: eredu batean euskarri izan daitekeen elementua hutsune nabaria izan daiteke bigarrenean.
\end{abstract}

\section{HITZ-GAKOAK:}

Gizarte bazterkeria, zaurgarritasuna, Diru-sarrerak Bermatzeko Errenta, genero desberdintasunak, hausturak.
El presente artículo pretende reunir los principales resultados derivados del trabajo de campo realizado para mi tesis doctoral. Su objetivo ha sido analizar la manera en que se configuran las situaciones de exclusión social entre personas perceptoras de la renta de garantía de ingresos (RGI). Para ello, el estudio se ha basado en dieciocho entrevistas en profundidad, realizadas a personas receptoras de la prestación con situaciones y responsabilidades familiares muy diversas. Se considera que, a pesar de que la RGI sea un importante punto de apoyo, resulta insuficiente para superar situaciones de vulnerabilidad. En cierta manera, el mismo título de la tesis recoge este punto de partida: "Vaivenes en los caminos de la vulnerabilidad, claroscuros de la renta de garantía de ingresos (RGI)". Esta expresión sugiere que la prestación se queda coja en la lucha contra la exclusión social. Partiendo de las múltiples maneras en que se concatenan los diversos ámbitos y factores de exclusión, se presentan como principal resultado dos modelos. Elementos que en el primero funcionan como puntos de apoyo, se transforman en ausencias notorias en el segundo.

\section{Palabras Clave:}

Exclusión social, vulnerabilidad, renta de garantía de ingresos, desigualdades de género, rupturas. 
Pobreziak beti urratzen ditu harremanak... ez bakarrik bikotearekin, baita familiarekin, lagunekin... zapuztu egiten da bat, osasuna ere hondatu egiten da... zure hezkuntza, auto-estimua... Argi eta garbi, pobrezia eta bizitza osasungarria, ez dira bateragarriak... (Aitor, elkarrizketatua).

\section{Sarrera}

Artikulu honen xedea, "Zaurgarritasun ibilbideetan balantzaka: Diru-sarrerak Bermatzeko Errentaren argi-ilunak" doktorego tesitik ${ }^{1}$ eratorritako emaitza nagusiak aditzera ematea da, batik bat landa lanetik ondorioztatu direnak. Helburuari heldu ahal izateko, ezinbestekoa da emaitzok testuinguru zabalago batean kokatu eta doktorego tesiaren inguruko zenbait xehetasun aipatzea. Horretarako, marko teorikoaren funtsezko ezaugarriak azaldu nahi dira behinik behin.

Ikerlan osoaren xedea, Diru-sarrerak Bermatzeko Errenta (DBE) prestazioaren ${ }^{2}$ onuradunen artean, gizarte bazterkeria nola itxuratzen den ikertzea izan da. Era berean, bigarren mailako ikerketa lerro gisa, beste hiru jomuga finkatu dira. Hasteko, familia esparruak zaurgarritasun istorioak zein bidetatik leundu edota biziagotu ditzakeen aztertu da. Bigarrenik, gizarte bazterkeria kontzeptu jarraitua izaki, haustura uneek bizitza ibilbideetan utzi dezaketen arrastoa miatu da ${ }^{3}$. Azkenik, hirugarren ikerketa lerro bezala, prestazioari buruzko ezagutzak onuradunen ibilbide pertsonalean izan dezakeen eragina ikertu da. Izan ere, prestazioa jasotzea norberari dagokion eskubidea dela bereganatzea, norberaren egoeran zeresana izan dezakeen faktoreetako bat dela uste izan dugu.

Ikerketa kualitatiboa izan da nagusiki, landa lana sakoneko elkarrizketetan oinarritu dela gogoan hartuz gero. Zaurgarritasun istorioak erabili dira gizarte eta ekonomia zaurgarritasunaren irudia taxuz marraztu eta soslaitzeko, eta baztertze prozesuon sakoneko esanahiak argitara ekartzeko. Zentzu honetan, gizarte bazterkeria bezalako kontzeptu batean murgildu eta ikerketa subjektuarengan zentratzeko tresna erabilgarria da elkarrizketa kualitatiboa. Ikerketa galderen baitan gatazkan ari diren emozioak nahasten diren egoerak ulertzeko eta fenomeno beraren inguruan inplikatuta dauden pertsona ezberdinek ikuspuntu anitzak pilatzen diren kasuak jorratzeko, oso lanabes aproposa da. Horretarako guztirako baliagarria izan zaigu hautatutako bide metodologikoa. Tesiko

1 "Zaurgarritasun ibilbideetan balantzaka: Diru-sarrerak Bermatzeko Errentaren argi-ilunak" doktorego tesia, 2013ko Maiatzaren zan defendatu zen. EHUko Ekonomia Aplikatua I departamentuan burutu da tesia, Mikel Zurbano Irizar eta Mertxe Larrañaga Sarriegik zuzenduta (Elorrieta, 2013).

2 Diru Sarrerak Bermatzeko eta Gizarteratzeko abenduaren 23ko legea 18/2008 Legea eta berau garatzen duten dekretua 147/2010 Dekretua maiatzaren 25ekoa dira prestazioa arautu eta erregulatzen duten lege nagusiak, eta 2011ko Azaroaz geroztik, 2008ko legea eraldatzen duen 4/2011 legea.

${ }^{3}$ Argibide gehiagorako, kontsultatu bizi ibilbideen teoria Glen Elder eta beste batzuen lanean Handbook of the Life Course liburua (2006). kapitulu analitikoan zehar, gure elkarrizketatuak izan dira protagonista nagusia. Oraingo honetan baina, ezingo diegu nahi beste arreta eskaini elkarrizketatik datozkigun narrazioei. Edozelan ere, hauek nolabait testura hurbiltzeko, hurrengo ataletan elkarrizketatuen bospasei pasarte tartekatu dira.

Azkenik, ekonomiaren esparrutik abiatu garen arren, esan beharra dago ikerketak ikuspegi multidiziplinarra barneratu duela. Izan ere, gizarte bazterkeria, ekonomiaz harago doan kontzeptua da, bizitzaren beste hainbeste esparru aintzat hartzen dituena. Horrek, derrigorrez, diziplina arteko ikasketa eskatzen du eta jarraian agertuko diren emaitzetan ere, diziplinartekotasun hori nabaria izango da.

\section{Ikerketaren marko teorikora hurbilketa}

Hurrengo paragrafoetan doktorego tesian jorratu den marko teorikoaren oinarri nagusiak zehaztu nahi dira, era laburrean bada ere. Lehenbiziko urratsean, ikerketan barneratu den gizarte bazterkeriaren ikuspegia ematen da aditzera. Era berean, lau ardatzeko eredua aurkezten da, erdigunean DBE prestazioaren onuradunak dituena. Bigarren azpiatalean, ostera, marko teorikoan eta ikerlanaren atal analitikoan genero aldagaiari eman zaion arreta berezia nabarmenduko da.

\subsection{Diru-sarrerak Bermatzeko Errenta prestazioaren onuradunak ikerketaren erdigunean}

Osoko ikerketa lanaren marko teorikoan, gizarte bazterkeriaren kontzeptu jakina txertatu dugu; hain zuzen ere, Kataluniako IGOP institutuak landu izan duena ${ }^{4}$. Ikuspegi honek, egiturazko fenomeno gisa aztertzen du bazterkeria, beronen izaera dinamiko eta erlazionala azpimarratuz (Subirats, 2005). Politikatik banaezina den fenomeno honek esparru anitz biltzen ditu bere baitan, eta horiexek hartu dira aintzat lan honetan; hala nola, esparru ekonomikoa, lan merkatuaren esparrua, harremanak, hezkuntza, osasunaren eremua, etxebizitza egoitza eta parte hartzearen esparrua.

Marko teorikoaren eraikitze prozesuan, gizarte bazterkeriaren kontzeptuaren inguruan lau esparrutan oinarrituta dagoen eredua eraiki dugu eta erdigunean, Diru-sarrerak Bermatzeko Errenta (DBE) prestazioa jasotzen duten pertsonak kokatu ditugu. Honenbestez, eredua sostengatzen duten esparruak hurrengoak izan dira; botere publikoak, enplegua eta harreman ekonomikoak finkatzen dituen merkatuen esparrua, familia harremanen esparrua eta azkenik,

${ }^{4}$ IGOP institutuak (Institut de Govern i Polítiques Públiques, Bartzelona) ibilbide sendoa jorratu du gizarte bazterkeriarekin lotutako gaietan. Bertako ikerketa talde batekin, Bartzelonako Diputazioarentzat egindako proiektu batean parte hartzeko parada izan nuen: Famílies, exclusió social i disrupcions en els cicles de vida. Proiektuaren helburu nagusia familia eredu desberdinek erakunde eta politika publiko desberdinekin eratzen dituzten harreman motak ulertzea izan zen (Ezquerra, 2011). 
harremanen esparrutik guztiz aldendu gabe, hirugarren sektorea eta elkarteen esparrua.

Esping-Andersenen eredu klasikoak lehen biak kontenplatzen zituen -lan merkatua eta estatuaren arteko elkarrekintza- ongizate erregimenak aztertzerako orduan (Esping-Andersen, 1993). Gerora autoreak berak ere planteamendu bikoitz hau gainditu egin du, hirugarren aktore gisa harremanen esparrua, edota zehatzago esanda familia barneratuz. Hala, hainbat autorek Andersenen eredu klasikoari aurpegiratu izan zaion genero itsutasuna nolabait zuzendu eta osatu egin dute (Korpi, 2000; Lewis, 2002; Orloff, 1996).

Bene-benetan erabakigarria den erlazioa ordaindutako lana, ordaindu gabekoa eta ongizatearen artean dagoena bada, ezinbestekoa da familia esparrua era esplizituan aintzat hartzea ongizate erregimenak aztertu ahal izateko (Taylor-Gooby, 1991). Hauek lan merkatuaren, familiaren eta estatuaren arteko elkarrekintzaren ondorioz finkatzen badira, genero aldagaia eta familiaren esparrua kontuan hartzeko elementuak dira (Esping-Andersen, 2000).

Gure analisian ere, behar-beharrezkoa izan da familiaren presentzia bistaratzea, ordaindu gabeko lanaren garrantzia eta era berean, emakumeen eta gizonen papera ere kontuan hartu ahal izateko. Are gehiago, aztertzen ari garen ongizate erregimena eredu mediterraneoaren barruan kokatzen badugu. Europa Hegoaldekoa gainontzeko ereduetatik desberdintzen duten ezaugarrien artean, familia inklusioaren baloreak duen pisua aipatu behar da. Familiaren baitan burutzen diren birbanaketa fluxu anitzak, alegia5.

Bigarren berezitasun gisa eredu hau duten herrialdeetan elkartasunak duen izaera mikroa azpimarratu da. Azken batean, familia ongizate erregimenen funtsezko euskarri gisa identifikatzen da eta aldi berean gizarte politiken garapen eskasa uzten da agerian (Moreno Fernández, 2000). Dena den, ongizate erregimenak errotik aldatzen ari dira azken urteotako korronte neoliberaleko erreformen ondorioz, eta horrek eredu aldaketa baten aurrean gaudela pentsatzera garamatza.

Behin harremanen esparrutik hirugarren sektoreak jokatzen duen papera bereiziz gero eta esparru honek ezaugarri eta dinamika propioak dituela onartuta, laugarren aktore bat gehitu diogu eredu hirukoitz honi (Subirats, 2004; Adelantado, Noguera, Rambla eta Saez, 1999).

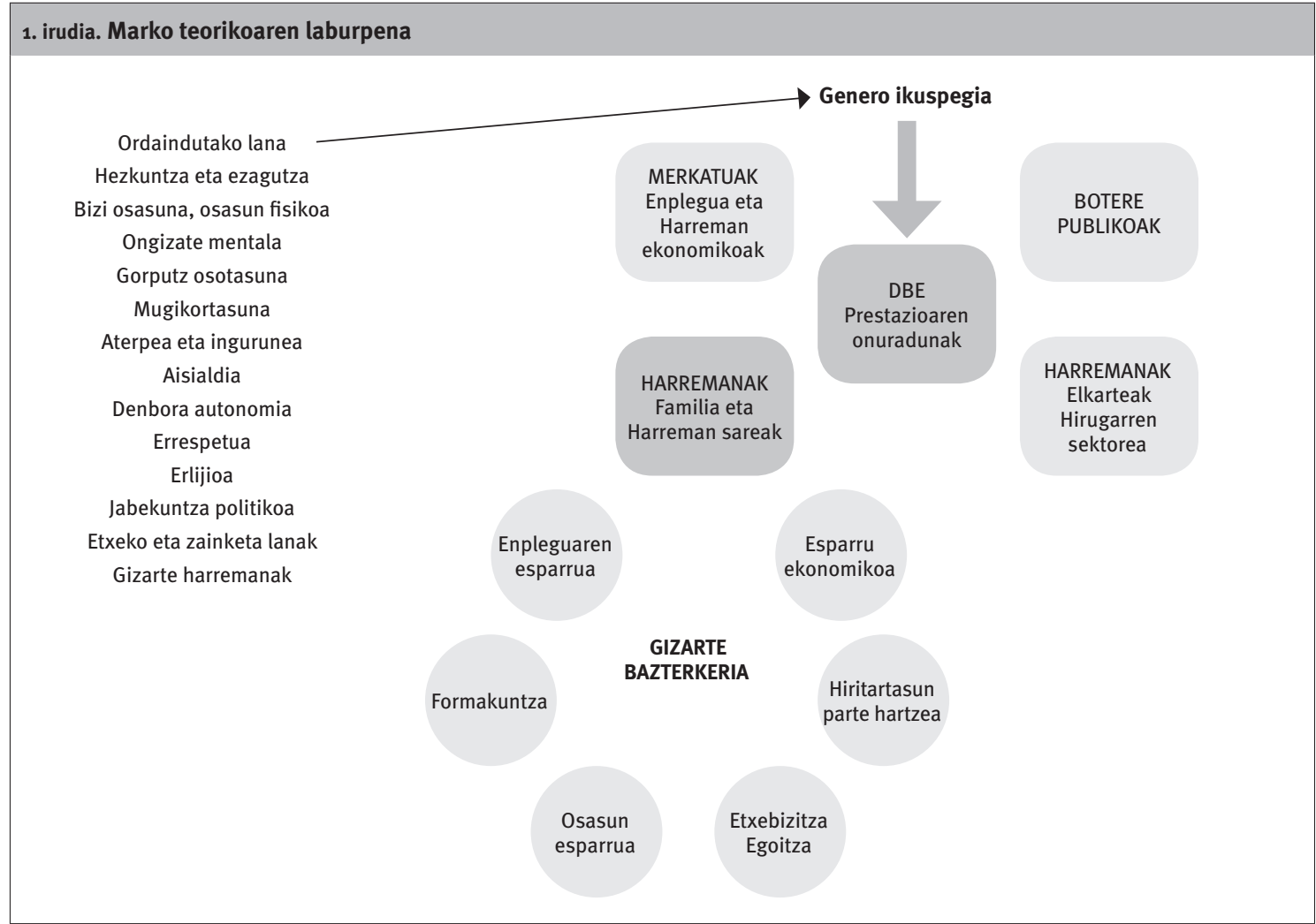

Iturria: egileak egina. 
Ondoko laburpen taulan ikus daitekeen moduan, DBE prestazioa jasotzen duten pertsonak izan dira ikerketaren jomuga (ikus 1. irudia). Pertsona hauei burututako sakoneko elkarrizketetan oinarritu da ikerketaren landa lana eta horren harira aitortzaren indarrari buruz hausnartu dugu.

Izan ere, aitortza, eguneroko solasaldietara hedatu den heinean, elkarrizketa kualitatiboetara ere hedatu dela argudiatu dute zenbait autorek (Gubrium eta Holstein, 2002), izan ere, elkarrizketa kualitatiboa egunerokotasunean zentratzen baita.

Testigantza hauek aintzat hartzerakoan, ez genuke pentsatu behar bazterkeria psikologizatzen ari garenik. Aitzitik, tresna honek daukan indarra izan behar dugu gogoan. Bazterkeriak pertsonak gogor jotzen dituela azaleratzeko metodologia honek duen gaitasunean ipini behar da arreta, prozesuaren erdigunean pertsonak daudela ahaztu gabe (Vidal, 2009). Gainera, elkarrizketa kualitatiboa gizarte bazterkeriaren egungo ezagutza hobetzeko aproposa da; fenomeno honen multidimentsionalitatearekin guztiz bateragarria izateaz gain harremanen esparrua oinarrizko dimentsioetako bat dela onartzen delako (Alfama eta Obradors, 2005; Subirats, 2006) ${ }^{6}$.

\subsection{Genero ikuspegia barneratu beharraz}

Bai marko teorikoaren eraikuntza prozesuan eta baita ikerketa lanaren atal analitikoan ere arreta berezia jarri da genero aldagaian, beroni zeharkako trataera eman nahian.

Analisiari dagokionez, generoari eskainitako atentzioa bereziki intentsua izan da gizarte bazterkeriaren harremanen esparruaz aritu garenean (familia egitura, etxeko arduren banaketa, amatasunaitatasuna). Honek guztiak, ezinbestean, badu bere isla emakumeek zein gizonek lan merkatuan duten posizioan, eta plano biak -lan merkatua eta harremana- banaezinak dira edozein azterketa egiterako orduan.

Alde teorikoan berriz, bi ikuspegi jakinek Ekonomia Feministarekin komunean dituzten elementuak azpimarratu dira (Larrañaga eta Jubeto, 2011). Hain zuzen ere, giza garapena (Sen, 1989) eta gaitasunen ikuspegiak, ekonomia feministarentzat duten potentzial handia nabarmentzen du Robeynsek (2003).

Bi ikuspegi hauen eta ekonomia feministaren artean lotura automatikoa egiten duen ezaugarria hurrengoa da: ongizatearen dimentsio anitz aintzat hartze horretan, gaitasunen ikusmoldeak eremu ez ekonomikoa azaleratu egiten du -esparru domestikoa-, horrekin batera ikuspegi ortodoxoek baztertu izan dituzten etxeko lan eta zainketa ardurei dagokien garrantzia emanez. Jakinik ardura hauek nagusiki

${ }^{6}$ Elkarrizketa kualitatiboari kapitulu oso bat eskaini zaio doktorego tesian. Besteak beste, Steinard Kvale (1996), Irene eta Herbert Rubin (1995), eta Miguel Vallesen (2003) eskuliburuak kontsultatu dira. emakumeek hartzen dituztela bere gain, ekonomia konbentzionalaren dualtasun horrekin haustea funtsezkoa da kritika feministarentzat (Larrañaga eta Jubeto, 2011; Robeyns, 2003, 2005; Picchio, 2003):

Pertsonen ongizatean eta abantailetan eragiten duten ezaugarriak hartu behar dira kontuan, bai merkatuarekin lotuta dauden bizitzaren aspektuak eta baita merkatuz kanpokoak ere, emakumeek merkatuz kanpo gizonek baino denbora gehiago ematen dutela aintzat hartuz (Robeyns, 2003).

Publikoa eta pribatuaren arteko dikotomia hori gainditzea -merkatua eta ez merkatua- beraz, garapenaren ikuspuntu honen abantaila gisa ikus daiteke. Amaia Pérez-Orozcok uste du, ordaindu gabe lanarengan jarritako arreta izan dela ikuspegi feministak Senen teoriari egin dion ekarpenik garrantzitsuenetakoa (Pérez-Orozco, 2006).

Paradigma honen izaera multidimentsionala bateragarria da azken hamarkadetan mugimendu feministaren borrokak defendatu izan dituen hainbat gairekin: osasun erreproduktiboa, bozkatzeko eskubidea, botere politikoa eta etxeko indarkeria, besteak beste (Robeyns, 2003). Honenbestez gaitasunen ikuspegiak, pertsonen bizitzako dimentsio anitzak barneratzen dituen heinean, gai horiek ere barneratzen ditu, berriz ere ekonomia konbentzionalaren ikuspegi monetarioa eta merkantilista gaindituz.

Bigarren abantaila gisa, ikuspegi feministarekin bateragarria den ezaugarri hau daukagu: gaitasunen ikuspegiaren izaera etikoki indibidualista eta ontologikoki ez indibidualista (Robeyns, 2003). Teoriaren erdigunean norbanakoa dagoen heinean, etikoki indibidualista dela esan daiteke. Baina bestalde, ikuspuntu ontologikoki batetik ez indibidualistatzat jotzen da; norbanakoaren gaitasun eta askatasun horiek beste pertsonekiko eta bizi diren gizartearekiko menpekoak ere badirelako. Izan ere, arau sozial edota diskriminazioen bitartez aldaketa faktoreek norbanakoaren aukerak baldintzatzen baitituzte.

Ikuspuntu feminista batetik, ezaugarri bikoitz hau desiragarria da. Alde batetik, emakumeak indibiduo propio gisa antzematen direlako, eta ez familia edota komunitatearen barruan lausotzen den elementu gisa. Baina aldi berean, norbanakoaren harreman sozialak, elkarmenpekotasunak ere kontuan hartzen dira eta zentzu honetan, merkatutik kanpo esparru pribatuan egindako lanak kontuan hartzea ahalbidetzen du, berriro ere.

Giza garapenaren eta ikuspegi feministaren arteko bateragarritasun honek ikerketari dakarkion beste onura bat, zaurgarritasun istorio hauen atzean dagoen aniztasunari aurre egiteko duten gaitasuna da, izan ere giza aniztasuna onartzeko era esplizitua baitaukate bi ikuspuntuek. Nolanahi ere, erne ibili beharra dago dibertsitate hori agertu nahian, emakumeak talde homogeneizatu batean ez sartzeko eta emakumeen artean ere dauden berezitasunak bistaratzeko. 
Kasu baterako, Nazio Batuen Garapenerako Programak darabilen Genero Desberdintasunaren indizeak emakumeek gizonekiko pairatzen dituzten desberdintasunak erakutsi nahi ditu. Giza Garapenaren Indizearen ildo beretik, indize bakar batean hiru dimentsiotan jasotako desberdintasunak barneratzen dira, zehazki bost adierazle bilduz. Batetik, emakumeek lan merkatuan duten parte hartzea daukagu. Bestetik, emakumeen jabekuntzari dagokionez, heziketa maila eta parlamentuan emakumeek duten jarleku kopurua hartzen dira kontuan. Azkenik, ugalketa osasunari dagokion esparruan, nerabeen emankortasuna eta erditzearen inguruko hilkortasuna neurtzen dira.

Indize trinko honek genero desberdintasunari dimentsio anitzeko trataera ematen diola onartzen badugu ere, botere eta rol jakin batzuk aztertzera mugatzen dela esan beharra dago eta beste zenbait faktore kanpo uzten dituela. Guri dagokigunez, elkarrizketetan parte hartu duten emakumeek ez dute botere postuetara sarbiderik, asko eta asko lan merkatuan parte hartzetik urruti daude, eta batzuek goi mailako ikasketak burutu dituzten arren, ez dira gutxi bigarren hezkuntzan gelditu zirenak. Azken batean beirazko sabaiaren oztopoa baino, zoru itsaskorraren tranpan harrapatuta dauden emakumeak ezagutu ditugu?

Honenbestez, gure protagonisten artean beste traza bateko faktoreek erakutsi digute hobeki emakumeek gizonekiko bizi ditzaketen bereizkeria egoerak; autonomia ekonomikoaren gabezia, etxeko arduren gainzama, indarkeria pasarteak, enplegua eta familia ardurak bateratzeko ezintasuna, besteak beste. Bestela esanda, botere terminoetan baino, beharbada botere gabezia eta ahultasun baldintzetan zentratu beharra dago, bai emakume eta bai elkarrizketatu ditugun gizonen kontakizunak aztertzerako orduan. Nolabait esatearren, ahotsa botere gabeei luzatu baldin badiegu, ahuldade horiei heldu behar zaie gure protagonisten egoera bistaratzeko.

Genero aldagaia eta gaitasunen ikuspegiarekin lotuta, Robeynesek proposatutako gaitasunen zerrenda barneratu dugu bai marko teorikoaren eraikuntzan eta baita analisian zehar ere (2003) [ikus 1. irudia]. Hain zuzen ere, Nussbaumek landutako hamar giza gaitasunen zerrenda testuinguru jakin batera mugatzeko intentzioarekin (1995, 2000, 2003, 2012), zerrenda alternatiboa ehundu zuen Robeynsek, zehazki mendebaldeko gizarteetan genero ezberdintasuna kontzeptualizatzea ahalbidetzen zuena $^{8}$.

7 Lan munduan botere postu gorenetara iristeko emakumeek gainditu beharreko zailtasun gehigarriak irudikatzen ditu beirazko sabaia horrek. Zoru itsaskorrak ostera, kontrako dinamika: beheko postuetan edota posturik prekarioenetan harrapatuta geratzen diren emakumeen egoera.

${ }^{8}$ Amartya Senen Gaitasunen ikuspegian sakontzeko, beste askoren artean, Sen (1985). Nussbaumen (2000) gaitasunen zerrendan aurkezten diren hamar dimentsioak: bizitza, gorputz osasuna, osotasun fisikoa; zentzumenak, irudimena eta pentsamendua; emozioak; arrazoimen praktikoa; afiliazioa; beste espezie batzuk; jolasa eta norberaren ingurunearen gaineko kontrola.
Honen harira, aztertu diren gizarte bazterkeriaren esparruetan zehar -ekonomikoa, etxebizitza, harremanak- zerrenda honetxen hainbat elementu txertatu dira. Honela, bazterkeriaren eremu ezberdinak aztertzearekin batera, lista honetako osagai askok ere gure azterketa gidatu dute: aterpea eta inguruneaz mintzatu gara, ongizate mentalaz, aisialdiaz eta denboraren autonomiaz. Genero eta harremanen esparruarekin lotuta, ordaindutako lanaz, eta etxeko lanez eta zainketez aritu gara.

\section{Landa lanaren emaitza nagusiak}

Lanaren xede nagusia, bizitza kontakizunei entzunaz gizarte bazterkeriaren ibilbideak nola profilatzen diren arakatzea izan da. Zalantzarik gabe, elkarrizketatutako hemezortzi bidaideen ibilbideak izan dira ikerketa lan honen aberastasuna. Ikerketa lerro nagusiak ardatz gisa harturik, aurre egituratutako sakoneko elkarrizketak burutu dira DBEren hamazortzi onuradunen artean. Jarraian datorren irudiak, oso era argigarrian bistaratzen ditu elkarrizketatu ditugun pertsonen perfilak zer-nolakoak izan diren:

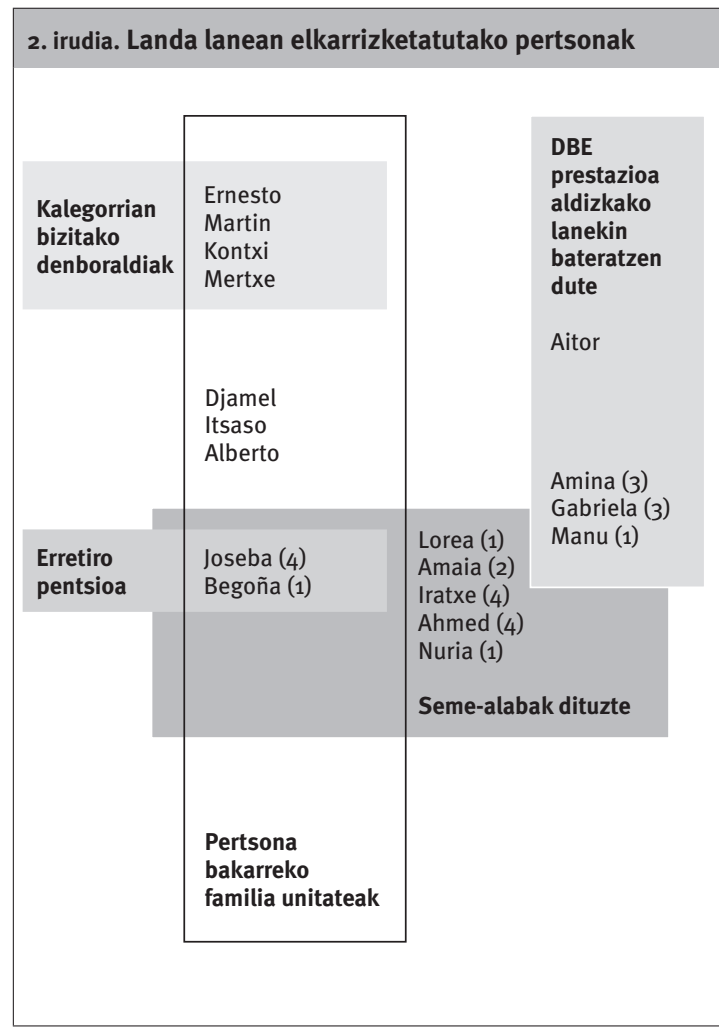

Iturria: egileak egina.

Bertan ikus daiteke, harreman, enplegu, etxebizitza eta bestelako esparruetan egoera aski desberdinak bizi dituzten pertsonak elkarrizketatu ditugula. Hau da, esparru ekonomikoari dagokionez, den-denak DBE prestazioaren onuradunak ditugun arren, gainontzeko eremuetan posizio ezberdinak dituzte; bakarrik bizi direnak, seme-alabak dituztenak eta ez dituztenak, 
prestazioa enpleguarekin konbinatzen dutenak, erretiroko pentsioa jasotzen dutenak, kale gorrian bizi izan direnak. Zentzu horretan ikerketaren helburu nagusiarekin bete egin dela esan genezake, elkarrizketa hauetatik guztietatik jasotako kontakizun eta bizipen sorta zinez emankorra izan delako. Aitortza hauek izan dira ikerketaren emari garrantzitsuenetako bat, eta era berean, haien testigantzak izan dira ikerketa honen aberastasunaren lekuko nagusia.

Bazterkeriaren esparru ekonomikoari dagokionez, bizpahiru ondorio azpimarratu gura dira. Lehenik eta behin, bizipen pertsonal hauek guztiak orokortuz anbibalentzia puntu bat duen emaitza jaso da: prestazioaren gutxiegitasuna ageri-agerian uztearekin batera, DBEren berebizikotasuna eta beharrezkotasuna nabarmendu dute behin eta berriro prestazioaren onuradunek. Hots, esparru ekonomikoan bizi dituzten estualdiak agertzen dituzte eta era berean, dirulaguntza honek egoera are gordinagoan bizitzetik ateratzen dituela onartzen dute.

Azken batean, dialektika hauxe bera lan honen izenburuan bertan iradoki da, prestazioaren onuradunak zaurgarritasun bideetan balantzaka bizi direla esatean. DBE prestazioak sostengu gisa balio diela bai, baina era berean, ez diela hauskortasun egoeratik irtetea ahalbidetzen.

Bestetik, baliabide ekonomiko gutxirekin bizitzeaz gain, hauskortasun egoerak berarekin dakartzan sentimendu anitzak ere zaurgarritasunaren parte banaezina direla ikusi dugu: hilabete bukaerara ezin iristeko beldurra, prestazioa bera galtzeko izua. Horrek guztiak ekar ditzakeen narriadura emozionala, frustrazioa, ziurgabetasuna, itomena eta zoramen sentimendua zaurgarritasunaren alderdi garrantzitsu dira eta sentimendu hauek gainontzeko esparruetara ere hedatzen dira. Azken batean, pobrezia ekonomikoak eragindako narriadura emozional horrek, beste esparru horiek urratu ditzake, harreman pertsonalak eta osasuna bera kaltetzeraino.

Honekin lotuta, orokortu ditzagun etxebizitzaren esparruaren inguruan bildu diren emaitzak. Dirusarreren proportzio handiena etxebizitza gastuak estaltzera bideratzen dela aintzat hartuta, argi geratu da etxebizitza esparruko beharrizanak asetzeko moduaren arabera guztiz baldintzatuta geratzen dela bizikidetza unitate bakoitzak daukan aurrekontua.

Kasuistika zabala bildu dugun arren, bi zertzelada nagusitan orokortu daitezke etxebizitzaren esparruan izandako ondorioak. Elkarrizketatuen artean, gehiengehienek laguntza edo babes iturri ezberdinak konbinatzen dituzte etxebizitza gastuak estali ahal izateko. Hartara, familia esparrutik, elkarteen mundutik edota administrazio publikotik -alokairu sozialak edota $\mathrm{EPOa}^{9}$ - datozkien laguntza gehigarrietara jo beha-

9 Etxebizitzarako Prestazio Osagarria (EPO), izenak dioenez, etxebizitza gastuak estaltzeko bideratzen den diru laguntza da. DBE prestazioarekin batera, izaera subjektiboa duen eskubidea da (18/2008 Legea). Zehazki, 2/2010 Dekretuak garatzen du EPO eta onuradunak rra dute. Era berean, bizikidetza unitatea pertsona bakarrekoa den kasurik gehienetan, etxebizitza beste pertsona batzuekin elkarbanatzea, beste aukerarik ez dute. Bestetik, ekonomia esparruan azpimarratu dugun ziurgabetasun sentimendua, etxebizitzaren esparruan ere oso presente dagoela antzeman da.

Puntu honetan, ikerketaren atal teorikoan jorratu dugun Nussabaumen gaitasunen ikuspegiarekin lotura interesgarri bat egin genezake. Segurtasuna filosofoak proposaturiko zerrendako gaitasunetako bat da. Zenbait elkarrizketatuen artean esparru ekonomikoan eta etxebizitzaren eremuan sumatutako segurtasun gabeziak, beraz, oinarrizko gaitasun baten hutsegitea utzi du agerian. Are gehiago, emaitza honek Wolff eta De-Shalit egileek dakarkiguten gaitasunaren segurtasun ideiaren garrantzia indartzen du (2007). Hots, unean uneko gaitasunak etorkizunean ere bermatuta egongo direla jakiteak ematen duen segurtasuna, berebiziko garrantzia duen elementua da. Honenbestez, segurtasun gabeziarekin eta beldurrarekin lotuta aipatu ditugun sentimenduek gizarte bazterkeria itxuratzerako orduan duten pisua baieztatzen da.

Ekonomia eta etxebizitza esparruaz gain lan merkatuari ere berebiziko arreta eskaini zaio. Bertan jasotako emaitza nagusiak laburtze aldera, ondorio orokor nagusi bat berreskura genezake. Lan merkatuan posizio, egoera eta ibilbide zeharo desberdinak dituzten pertsonekin egin dugu topo. Mutur batean lan merkatutik erabat deslotuta eta urrunduta daudenak ezagutu ditugu, etorkizunera begira ere, enplegu bat aurkitzeko oztopo nabariak bizi dituztenak. Hau $\mathrm{da}$, lan merkatutik urteetan aldenduta egon diren pertsonak.

Beste muturrean lan merkatuarekin harremana izanik ere, baldintza oso prekarioetan mugitzen direnak ezagutu ditugu: langabezia eta aldizkako lanak bata bestearen atzetik kateatzen dituztenak, seme-alaben zaintza eta enplegu bat bateragarri egiteko oztopoak dituztenak, adina eta genero arrazoiengatik haien prestakuntza mailarekin bat datorren lanpostu bat lortzeko trabak dituztenak, lanaldi osoko enplegu bat topatu ezinean dabiltzanak.

Egoera aniztasun honetatik pixka bat urrunduz, hurrengoa ondoriozta genezake: lan merkatuarekin duten -edo ez duten- harremanak ez die gure elkarrizketatuei bazterkeria edota pobrezia egoeratik aldentzea ahalbidetzen. Kasu batzuetan, enplegu prekarioena sostengu, motibazio, pizgarri eta diru iturri gehigarri garrantzitsu izan daitekeela sumatu dugun arren, ez du enplegu horrek nahikoa berme eta segurtasun eskaintzen. Azken batean, DBE lan merkatuan txertatzeko jarrerarekin lotuta dagoen eskubidea izanik, kolokan geratzen da erabat enpleguari atxikitzen zaion gizarteratzeko funtzioa. Era berean, enpleguaren zentraltasun horrek frustrazio sentimenduak eragin ditzakeela egiaztatu da.

$\overline{\text { baldintzak betetzen dituen kasuetan, prestazio osagarri honek ohiko }}$ DBE konplementatzen du. 
Arestian aipatu ditugun hiru ikerketa galderen inguruan ere emaitza interesgarriak bildu dira. Horiek ardatz gisa harturik, segidan ondorio nagusiak laburtu gura dira. Lehenik eta behin, zaurgarritasun ibilbideetan hausturek izan dezaketen eraginari dagokionez, haustura hauek norbanakoarentzat duten esanahiaren garrantzia azpimarratu dugu. Esangura horren eraikuntzan, haustura hori ikusteko bakoitzak duen modua berebizikoa da, eta horretan, erabilitako terminologiak daukan garrantziaz konturatu gara. Ez zaio haustura hitzari konnotazio ezkorrik eman nahi izan gure planteamenduan, baina zenbait elkarrizketatuk zer pentsatua eman digute eta horrek, haustura terminoarekin batera beste adierazpide batzuk erabiltzeko aukera ireki digu. Hala, lotura puntu, berreskuratze puntu, eta aukera une terminoen erabilera txertatzea proposatu da.

Haustura, une esanguratsu, aukera uneek bizitzako esparru anitzetan utzi dezakete arrastoa. Dena den, batzuetan posible da une esanguratsu jakin bat bizitzako esparru jakin batekin erlazionatzea. Familia esparruan bizitako aldaketak -bikote hausturak, haserrealdiak, urruntzeak, seme-alabak izatea- oso era desberdinetan bizi izan dituzte gure elkarrizketatuek, baina gizarte bazterkeria egoera larrienak bizi dituzten pertsonen artean, emaitza bat orokortu genezake. Izan ere, bazterkeria latzenean bizi direnen artean, guztiek izan dituzte haustura esanguratsuak familiaren esparruan.

Honek bigarren ikerketa galderari buruzko ondorio nagusiak aipatzera garamatza, hain zuzen ere, lan hau gidatu duen beste ikerketa galdera, familia esparruarekin lotuta dago eta. Xedea, zaurgarritasun ibilbideetan familia esparruak joka dezakeen papera arakatzea izan da, bazterkeria egoerak leundu edo biziagotzeko familia esparruak izan dezakeen gaitasuna aztertzea.

Era oso xehean aztertu da baliabide ekonomikoekin estali ezin diren beharrizanak familia esparruaren laguntzari esker zelan asetzen diren. Babes horrek har ditzakeen itxura anitzak miatu ditugu, eta kasu askotan, familia ondoan dagoela jakite hutsak ematen duen bermea, ziurgabetasun sentimendua leuntzen duen faktorea dela sumatu da.

Alderantziz, esparru hori ez dagoen kasuetan edo huts egiten duenetan, berme horren faltak ziurgabetasun sentimendua areagotu egiten du. Hau da, beste behin ere familiak eman dezakeen sostengu finantzario eta emozionalaz gain, segurtasun gabezia, bakardade eta laguntasun sentimenduak indar eztabaidaezina duten faktoreak dira, zaurgarritasun ibilbideen parte direnak.

Hirugarren ikerketa galderak DBEren onuradunek prestazioaren beraren inguruan duten ezagutza mailari buruz gogoeta egitera zuzendu gaitu. Landa lanean zehar ere, subjektuak prestazioa jasotzea berari dagokion eskubidea dela barneratuta duen ala ez aintzat hartu beharreko elementua dela egiaztatu ahal izan da, eta honen harira kontraesan oso interesgarriekin egin da topo. Norberak prestazioari buruz duen jabekuntza maila eta iritzia, ingurukoek izan ditzaketen jarrerekin borrokan sartzen denean, kontrajarriak izan daitezkeen sentimenduak pizten dira. Eskubidearen ezagutza eta barneratzea prozesu indibidual eta kolektibo baten emaitza da, norbere auto-estimuan eta gizartean pairatzen duen estigmatizazioan zeresan handia duena. Ondoko pasarteak, auzi honen muinera garamatza:

Gauza bat da nik zer pentsatzen dudan, eta gero beste bat, zuk zer sentitzen duzun horrelako egoera batetik pasa behar duzunean... ba sentitu izan naiz, nolabait lotsatuta. Zergatik? Baliteke izatea jasotzen nuen diru hori ez nuela behar, edo ez nuelako eskubide hori eduki behar... baizik eta, azken batean da nolabait... nabarmentzen dela gai zarela bizitzeko normal, normaltasun horrekin. Eta normaltasun horrek esan nahi du gai zarela lan egiteko eta hor bai badagoela zure buruarekin horrelako kezka bat. Esaten duzu, 'baliteke ez nahikorik egin izana lana bilatzeko'. Ez dut edozein lan bilatzen? Oso gogorra da, ze gainera nire ustean, gehienbat da hori, nolabait zure auto-estima... ba hori kolokan ipintzen da, ez? Ez zara gai aurre egiteko zure familiarekin... (Amaia, elkarrizketatua).

Jarraian datorren irudiak, orain arte aipatutako emaitza nagusiak biltzeaz gain, genero aldagaiarekin lotutako ondorio gehienenak ere ematen ditu aditzera. Izan ere, Robeynsek Mendebaldeko gizarteetarako proposatu zuen zerrenda horren helburuetako bat genero desberdintasunak ageriko egitea izanik (2003), gure ikerketan ere genero aldagaia desberdintasun ardatz gisa jorratu da, eta alderdi horretatik, bi ezberdintasun lerro nagusi adierazi ditugu.

Batetik, seme-alaben zaintza beregain duten emakumeek enplegu bat aurkitzeko bizi dituzten zailtasun gehigarriak izango genituzke. Horrek eremu ekonomikora dakartzan muga nabariez gain, esparru pertsonalean eragina izan dezake:

lan bila ari naiz, eremu pertsonalean, emakume moduan garatzeko beharra dudalako, lana egiteko beharra dut, diruagatik baita ere... Nire bizitzako une honetan, nire emakume identitatea galtzen ari naiz... ama naiz, ez-dakit-noren ama naiz, ez-dakit-noren ama... eta kokoteraino nago! (Lorea, elkarrizketatua)

Bigarren desberdintasun lerro gisa, familia arduren gainzamarekin lotuta etor daitezkeen isolamendu eta bakardade sentipenak aipa genitzake, beste behin ere, emakumeak etxetik kanporako eszenatokitik urrunarazi ditzakeena. Bi desberdintasun lerro hauek elkarrekin jarduten dutenean, genero aldagaiak desberdintasun ardatz gisa jokatzen duen funtzioa biderkatu egiten da.

ahaleginak egiten eta bueno, horrelako egoeratan, emakumeak nolabait eskizofreniko bihurtzen dira, eta horrela egon naiz eskizofreniko. Oso gogorra izan da, eta gero, ba orain begiratuta ez dakizu nola egin duzun, nola jasan duzun hainbeste tentsio... (Amaia, elkarrizketatua). 


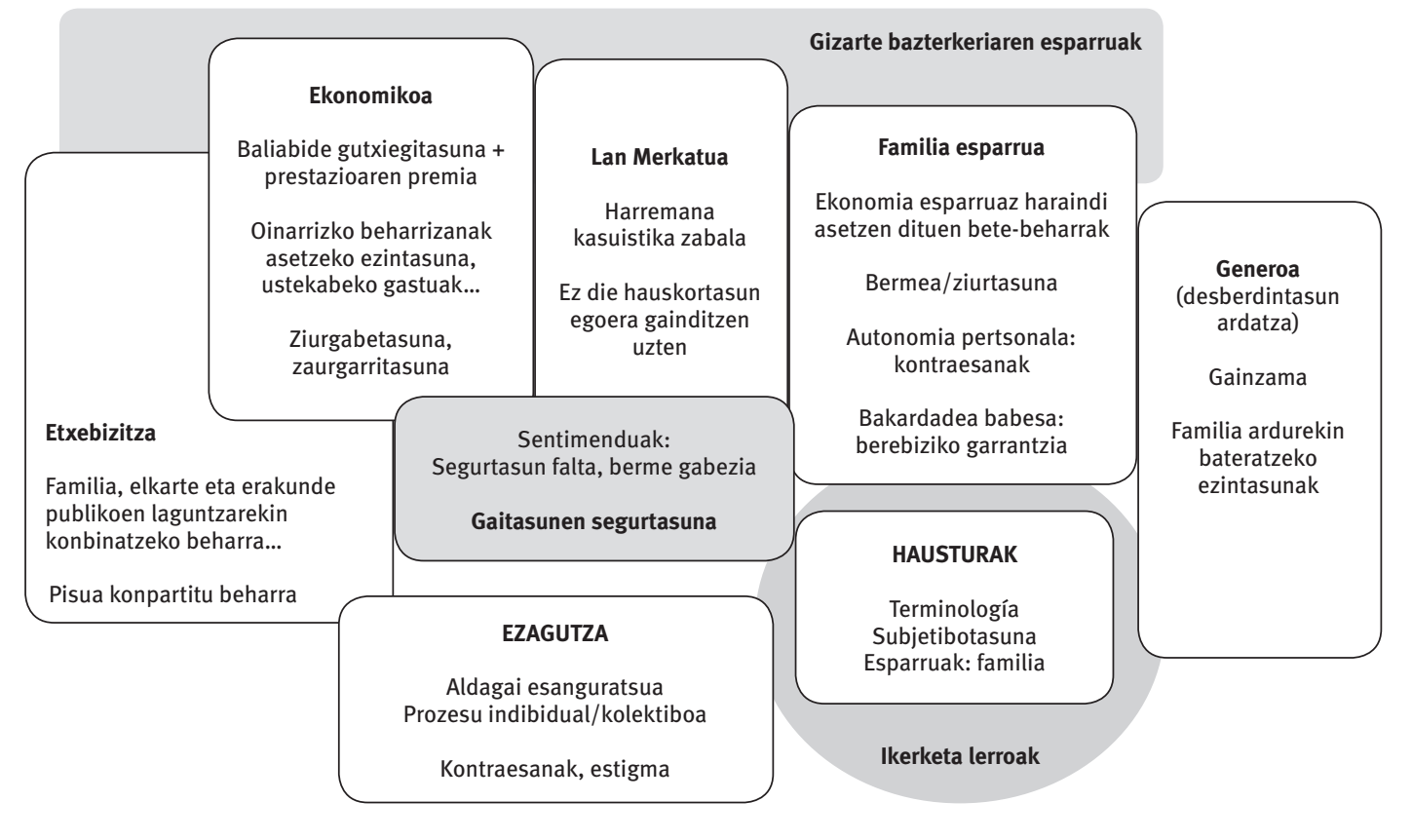

Iturria: elkarrizketa kualitatiboetatik abiatuta, egileak egina.

\section{Zaurgarritasun ibilbideak: bi dinamika ondo-ondoan}

Ikerketaren ondorio nagusiak aurkeztu ondoren ikerketa lanean zehar ehundutako hari mutur nagusiak lotu nahi dira. Azterketaren erdigunean DBE prestazioaren onuradunak izan ditugu aldi oro eta beraz, ezin ahantz dezakegu prozesu osoan zehar 'subjektua' izan dela gure protagonista nagusia. Horixe izan da hain zuzen ere lan honen aberasgarritasun nagusia: hamazortzi pertsona ezberdini boza eman eta haien narrazioei arretaz jarraitzea.

Segidan datozen irudiek burututako elkarrizketa kualitatibo guztien artean antzeman diren bi dinamika nagusi laburbiltzen dituzte. Honen helburua ez da hamazortzi begirada ezberdinek eman digutena bi multzotara murriztea, inolaz ere. Ezta gure protagonistak talde edota kolektibo itxietan barneratuz emaitzak sinplifikatzea ere, ariketa antzua bailitzateke hori.

Ikerketaren helburu nagusiari jarraiki, lanean zehar gizarte bazterkeriari eta bazterkeriaren ibilbideei forma ematen dioten esparru anitz aztertu ditugu, baita faktore hauek pertsona bakoitzaren kasuan elkarren artean nola jokatzen duten ere. Beste elementu askoren artean bizitza kontakizunetan izandako hausturak landu ditugu, lan merkatuarekin duten harremana, inguruan izan dezaketen familia eta lagun sarearen garrantzia, prestazioaren inguruan daukaten ezagutza maila, etxebizitza beharrizanak nola asetzen diren.
Jakina narrazio bakoitza apartekoa eta errepika ezina dena, baina nolanahi ere singulartasun horri uko egin gabe, gizarte bazterkeria itxuratzen duten faktoreen arteko konfigurazioan hein batean errepikatzen diren bi eredu identifikatu dira gure laginean. Edo doiago izateko, 'eredu' esan ordez, faktoreen arteko joko dinamikaz arituko gara.

Hau da, bazterkeria faktoreak eta esparruak elkarren artean kateatu eta endredatzeko dauzkaten era amaigabeen artean bi jokabide edo profil nagusi nabarmendu dira. Faktore hauek bata bestearen artean konbinatu eta metatzeko dauzkaten joera dinamikak dira beraz islatu nahi direnak eta ez prestazioaren onuradunen profilak.

Ekonomia bezalako zientzia baten baitan ere, ikerketa kualitatiboak teoria berreraikitzeko ematen duen aukera argudiotzat hartuta (Piore, 2006), elkarrizketa sorta honek emandakoaz elikatu gara gizarte bazterkeria itxuratzen duten zenbait faktore eta eremuren arteko portaera ereduak eraikitzeko.

Ikerketaren xede nagusia, pobrezia ekonomikoa eta gizarte bazterkeria nola perfilatzen diren ikastea izan dela gogoan izanik eta elkarrizketa kualitatiboak teoria berritzeko ematen digun egokiera profitatuz, jarraian aurkeztuko diren bazterkeria faktoreen arteko joko dinamikek emaitza biziki interesgarriak jaurtitzen dituzte: 

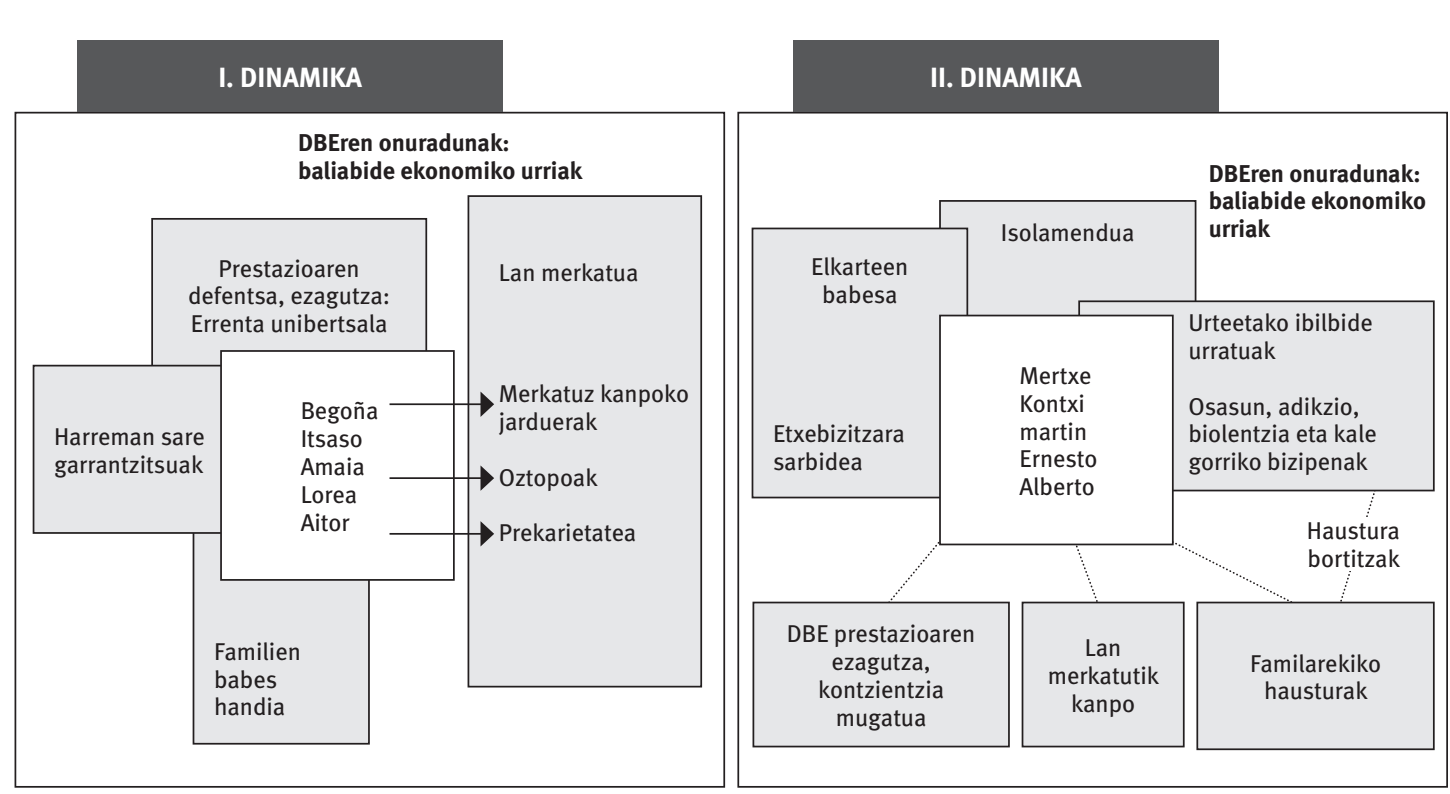

Iturria: elkarrizketa kualitatiboetatik abiatuta, norberak eginda.

Lehen multzoan adierazitakoa, zenbait narraziotan behatutako dinamikekin dator bat. Ereduaren atzean dauden kontakizunak ez dira erabat paraleloak baina modu zabalean parekotasun nabariak dituzte. Hasteko DBEren gainean ezagutza nahiko zabala erakutsi dute eta eskubidearen defentsa irmoa egiteaz gain, HOE unibertsalarekin lotutako nozio batzuk ere badauzkate. Neurri apalagoan nahiz sutsuki, hiritar orori zuzendutako prestazioaren alde egiten dute, mugimendu sozial eta politikoetan murgilduen daudenek bereziki.

Eskubidearen inguruko ezaguera izateak, ez du berak bakarrik inplikatzen pertsona hauek bazterkeria egoeratik libratzen direnik, ezta erosoago biziko direnik ere. Nahiz eta prestazioaren gaineko kontzientzia handia izan dezaketen, norbere baitan sortzen diren kontraesanenen eta estigmatizazioaren aurka borroka egin beharra dago. Baina zalantzarik gabe abantaila garrantzitsua da, hauskortasun egoeraren barruan sostengu sendoa, eta auto-estimua indartzen laguntzen duena.

Harremanen esparruari dagokionez ingurune aski egonkor eta aproposa dutela erakutsi digute. Bakoitzak bere errezeta propioarekin, baina senide eta adiskide sareekin harreman jariotsua gordetzen dute. Iraganean eta gaur egun ere haien aldetiko babesa jaso izan dute; dela era iraunkorrean, dela une puntualetan zailtasunen bati aurre egiteko.

Horretaz gain, harreman sare horien inguruan eta gizarteko beste espazio batzuetan ere parte hartzen dute gehienek, maila desberdinetan bada ere: dela ikasten jarraitzen dutelako, eskolako gurasoen elkartean daudelako, edota gizarte mugimendu eta elkarteetan partaidetza aktiboa dutelako.
Gainontzeko elkarrizketatuen aldean ezin esan daiteke egoera ekonomiko oparoagoa dutenik eta besteek bezala estualdi uneak bizi dituzte: zailtasunak dituzte hilabete bukaerara iristeko, etxebizitza gastuak estaltzeko eta ustekabeko egoerei edota aparteko gastuei aurre egiteko. Argi geratu da prestaziotik jasotzen dutenarekin nekez ase ditzaketela oinarrizko beharrizanak ere, baina beste lagunekin parekatuz, harremanen esparruan daukaten 'aterpeak' babes handia ematen die bai beharrizan materialak zein emozionalak betetzeko ere.

Familia eta lagunek emandako laguntza honek badauka garrantzi gehigarria beste bi zentzutan ere. Hasteko, inguruan sare babesle bat dagoela jakite hutsak sentiaraz dezakeen bermea daukagu. Horrekin batera, sare hori bera gertu izateak muturreko beste egoera batzuetan sentitu daitekeen isolamendu eta bakardade egoeratik urrun dezake bat.

Honek elkarrizketatutako etorkinen inguruan gogoeta txiki bat egitera garamatza. Izan ere, atal honetan plazaratutako bi ereduetan ez dugu etorkinik barneratu, beraien ibilbideak ez baitira bazterkeria faktoreen joko dinamika hauetara egokitzen. Azalpen posible bat hurrengoa litzateke: familia esparru hau fisikoki urrun edukitzeak sare babesle horren hutsunea dakar berarekin, jatorrian elkartasun harreman sendoak egon daitezkeen arren.

Bestalde, harremanen esparrura itzuliz, kontuan hartu behar da norberaren autonomiarengatiko premiak eta desioak aurrez aurre egiten dutela talka familia esparruarekiko sor daitekeen menpekotasun harremanarekin. Autonomia hori muturreraino garatu ezinak kontraesan eta frustrazio sentsazioak ekar 
ditzake berarekin, eta egokiera hori zaurgarritasunaren parte ukaezina da.

Era berean lan merkatuarekin daukaten erlazioa hauskorragoa erakusten digu grafikoak gezi bidez adierazten den lotura horren bitartez. Hau da, lan merkatuarekin harremana duten pertsonak diren arren, lotura hori ez da batere egonkorra; enplegu bat lortzeko oztopoak, bata bestearen atzetik kateatzen diren enplegu prekarioak, edota guraso bakarreko familien buru diren emakumeek izan ditzaketen traba gehigarriak dira ahultasun horren adibide.

Ezegonkortasun hori kontuan izanik ere berebizikoa da nabarmentzea ez direla lan merkatutik erabat desmarkatuta dauden ibilbideak; iragan laburrean lanean aritu izan direlako, elkarrizketak egiteko unean lan bila ari zirelako, edota epe ertainean enplegu bat aurkitzeko esperantza zutelako.

Honenbestez, grafikoan protagonisten ezizenen azpian agertzen diren hiru laukiek berauen itzala bailiran pertsona hauei ematen dieten euskarria irudikatzen dute. Prestazioa jasotzeko eskubidearen ezagutza, inguruko harreman sare sendoa eta familiak emandako babesa dira, bat eginda, gure lagunei nolabaiteko bultzada ematen dietenak. Laugarren euskarri gisa, lan merkatua markatzen da, baina aipatu dugun bezala eremu horrek emandako sostengua makalagoa da.

Sostengu horiek, halaber, gizartearekin daukaten loturaren ikur ere badira, eta zaurgarritasun egoeran bizi diren arren, ezin genezake esan gizartetik deserrotuta dauden pertsonak direnik. Ondoko pasarteak, ederki biltzen du orain arte jasotakoa:

Adiskideak baditut, ez daukat inolako menpekotasunik, ez arazo psikiko edo psikiatrikorik, ikasketak baditut, mugitzeko gaitasuna... gizarte proiektuetan parte hartzen dut. Norbaitek bazterkerian nagoela esaten badit... zera esango diot: baztertua izango da, diru asko daukana eta etxean sartuta dagoena, Play Stationera jolasten, komunikatzeko arazoak izango ditu. Niri dirua ematen badidazu... baztertuen kolektibo horretatik atera nazakezu. Dirua falta zait, besterik ez (Aitor, elkarrizketatua).

Eskumako irudiak ostera, elkarrizketetatik ondorioztatu dugun bigarren joko dinamika adierazten $\mathrm{du}$, bi ereduen artean topa daitezkeen nolabaiteko asimetriak agerian utziz. Ez dira elkarren artean kontrajarriak diren dinamikak baina azken batean, eredu batean pilare izan den elementu edo faktorea hutsune nabaria izan daiteke beste ereduan. Batean egonkortzailea dena, ezegonkortasunaren sortzaile bilaka daiteke.

Lehenik eta behin aurreko modeloan euskarri gisa seinalatu ditugun faktoreek bestelako jokabidea erakutsi dute bigarrenean. Grafikoki protagonisten itzal gisa irudikatu ditugu lehen, eta orain berriz, pertsona hauengandik urrunduta irudikatu dira, eten- dura puntuen bitartez lotuta. Zentzu honetan lehen sostengu zirenak, orain, pertsona hauek bizi diren gizartetik nolabait deslotzen dituzten elementuak dira; desmarkatu egiten dituztenak.

Elementu hauen artean hiru, lan honetako ikerketa galdera nagusiekin era estuan lotuta daude; bai familia esparruak jokatzen duen rolarekin bai hausturek bizitza ibilbideetan utz ditzaketen arrastoekin, eta baita eskubidearen ezagutzarekin ere.

Honenbestez, atal honetan proposatuko emaitzak zentzu bikoitz batean dira esanguratsuak. Batetik ikerketa xede nagusiari dagokionez, bazterkeria faktoreen arteko joko dinamika bi proposatzen direlako, eta bestetik, bi dinamika zehatz hauetan ikerketa galderen inguruan lortutako emaitzek bere lekua propioa dutelako.

Bide batez, beste behin ere gaitasunen ikuspegiarekin lotura eginez Wolff eta De-Shalitek (2007) proposatzen dituzten 'desabantaila korrosibo' eta 'funtzionamendu emankorrarekin' paralelotasuna egin dezakegu bi eredu hauen arteko asimetriak azaltzeko. Hartara, funtzionamendu emankorrek beste zenbait gaitasun -edo bizitzaren esparru- garatu arazten lagun dezakete. Esaterako, I. joko dinamikan harremanen sare garrantzitsuak eta prestazioaren ezagutzak jarduten duten bezala. Alderantziz, II. joko dinamika honetan drogamenpekotasun arazoek edota indarkeria pasarteek desabantaila korrosibo gisa jokatzen dute bizitzako beste esparru batzuk ere mugatzen dituzten heinean.

Irudian ikus daitekeenez, batetik prestazioaren inguruan duten ezagutza eta kontzientzia eskasa nabarmentzen da. Jakitun dira bai, dirulaguntza baten onuradun direla baina ez dute prestazioaren beraren izaera eta horren atzean dagoena ezagutzen. Aspektu horretan, beraz, ez daukate bizi duten errealitatearen berri eta horixe deslotura puntu bat bezala sumatu da.

Urteetan urratutako ibilbideak dira, bazterkeria faktore ezberdinak metatu dituztenak: alkoholismo arazoak, drogarekiko menpekotasuna, indarkeria pasarteak edota buruko osasun arazoak. Azken batean, haien zaurgarritasuna biziagotzen duten bizipenak dira. Familia esparrutik eta lan merkatutik deserrotutako ibilbide urratuak dira, parte hartze eta babesgune gisa hain garrantzitsuak diren bi espazio horietatik at geratzen direnak.

Ez dute luzaroan enplegurik izan eta etorkizunera begira ez dute haien burua lan merkatuan integratzeko gai ikusten; ez du zertan diagnostikatuta daukaten gaixotasun edo ezintasun batengatik izan behar, baina mundu horretatik deserrotuta sentitzen dira nolanahi ere. Enplegua zentrala den ikuspegi batetik, epe luzera ere 'enpleagarritasun' txikia duten pertsonak direla esan genezake.

Emaitza honi lehendabiziko joko dinamika taulan lortutakoak gehitzen badizkiogu, enpleguak eta lan 
merkaturako txertatzeak gure elkarrizketatuen artean jokatzen duen rola ondoriozta daiteke. Enpleagarritasun baxuko pertsonak; gizarte prestazioen onuradun kronifikatuak; seme-alabak zaindu eta aldi berean bateragarria den enplegu bat bilatzeko oztopoak dituztenak; enpleguren bat aurkitzekotan, aldizkako lan prekarioak eta langabezia tartekatzen dituztenak; den denak egoera asistentzialetik atera ezinean dauden pertsonak dira.

Ondorio bertsuak jaso ditu Mari Luz de la Calek ere Euskadiko Babes Politikaren egoera eta erronkak aztertzen dituen artikuluan (De la Cal, 2012). Orotara daukagun emaitza, zaurgarritasun ekonomikotik irtetea ahalbidetzen ez duen eta lan merkatuari lotuta dagoen prestazioa litzateke.

Berriro ere bigarren irudira itzuliz, harremanen esparruan senideekin izandako urruntze garrantzitsuak adierazi dira bertan, kasu batzuetan sare horren erabateko absentzia punturaino iritsi diren hausturak, hain zuzen ere. Azken batean, gabezia horrek berekin dakarrena zera da: familia esparruak eskaini dezakeen babesarekin kontatu ezina.

Irudian deslotura elementu gisa irudikatzen dira beraz lan merkatuarekin eta familiarekin duen harremana, eta baita prestazioaren inguruko ezagutza falta ere. Horrekin batera, euskarri edo elementu mugatzaile gisa beste hiru ezarri dira.

Lehen elementua, aipatuta dago honezkero: zaurgarritasun egoeran luzaroan egon diren ibilbide hauetan faktore gehigarriak metatzen dira. Bestetik, familia ingurunearen absentzia hori betetzeko, hirugarren sektoreak joka dezakeen sostengu papera ere badugu. Babesgabetasun egoeratan elkarte eta gobernuz kanpoko erakundeek betetzen duten paper osagarria bi puntutan izan da erabakigarria aztertutako narrazioetan zehar. Bestela esanda, oinarrioinarrizkoak diren bi beharrizanen hornitzaile edo bermatzaile gisa antzeman dira elkarteak, prestazioa jaso ahal izateko eta etxebizitza beharrizanak asetzeko sarbidea errazten duten heinean.

Elkarrizketatuek duten baliabide ekonomikoen gutxiegitasuna aztertu dugun momentuan etxebizitza gastuek daukaten protagonismoa azpimarratu dugu. Azken batean etxeko aurrekontuaren zatirik handiena baitagokio kontzeptu honi. Egoitza etxebizitza IGOPek jorratzen duen gizarte bazterkeria kontzeptuaren esparruetako bat da, eta Robeynsen zerrendan (2003) agertzen den gaitasunetako batekin estu lotuta dago, 'aterpea eta ingurunea' gaitasunarekin alegia.

Elkarrizketetan zehar behatu ahal izan dugun moduan, gure protagonistek nekez ase ditzakete etxebizitza gastuak inori laguntzarik eskatu gabe; familia esparruaren laguntzara, elkarteen babesera edota EPO prestaziora jo beharra dute alokairua ordaindu ahal izateko. Bigarren irudi honetan adierazitako bazterkeria faktoreen joko dinamikan, hirugarren sektoreak etxebizitza gastuak estaltzeko orduan jokatzen duen papera da hemen nabarmendu nahi duguna.
Azkenik, hirugarren elementu mugatzailea isolamendua bera da, bazterkeria faktoreen joko dinamika hauetan zaurgarritasun egoera hobeki islatzen duena. Oso jende gutxirekin erlazionatzen diren pertsonak direla ikusi ditugu; ez lagunekin, ezta ikastaroak eginez ere, ez gizarte mugimenduetan. Bakardade sentimendu sakona erraietaraino barneratzen denean, edo are gehiago bakartze prozesuen gailurra jotzen denean, bazterkeria errealitate are gordinagoa bilakatzen da.

Oso bakarrik, ez daukat lagunik, ez daukat inor... pisuko besteak ez dira lagunak... Bidean zehar nire bizitzaren zati bat utziz joan naizela sentitzen dut... Hiltzeko ordua iristen zaidanean, denoi iritsiko zaigu eta... ordurako pixka bat hilik egongo naiz jada. Hiltzen joan naiz eta... gertatu zaidan gauza bakoitzak, pixka bat hil arazi nau... (Kontxi, elkarrizketatua).

\section{Azken hausnarketa}

\author{
Haientzat bazterkeria ekonomikoa eta soziala \\ elkarrekin doaz, baina kuriosoa da gero, gizarte \\ bazterkerian zaudenean nola uzten zaituzten \\ bertan behera... (Aitor, elkarrizketatua).
}

Gizarte bazterkeria kontzeptu jarraitua da, etenik gabekoa, continuum bat. Bizitza ibilbideei so eginez, zaurgarritasun kontakizunen konplexutasunarekin egin dugu topo bekoz beko. Narrazio hauek ere bete egiten dute jarraitasun ezaugarri hori, beti baitoaz aurrera. Aitzina joateak ez du derrigorrez esan nahi ibilbideek linealak izan behar dutenik. Izan ere, ez dago aurrera egiteko modu bakar bat; bide hauek itxura anitzak har ditzakete eta ikuspegi zikliko batetik ere azter litezke.

Bizi-lerro hauen norabidea aldakorra da, etengabe muda daiteke. Aldaketa hauetariko batzuk trantsizio edota inflexio puntu bat markatzen dutenean bereziki esanguratsuak izan daitezke norbanakoarentzat. Eta, norbere ikuspegiaren arabera, une horiek haustura, aukera, edota berreskuratze puntu gisa antzeman daitezke.

Burututako elkarrizketa horien guztien artean bizipen eta istorio zeharo ezberdinak bildu dira. Gizarte bazterkeria kontzeptu jarraitua izanik ere, pobrezia ekonomiko soilean bizi diren pertsonak izan ditugu alde batetik; baliabide ekonomiko urriak dauzkatenak. Bestetik, bazterkeria ekonomikoaz gain, bizitzaren beste esparru garrantzitsuetan ere bazterkeria larria pairatzen dituztenak ere ezagutu ditugu. Honenbestez, posible da jarraitasun honen barruan muturrekoak diren egoerak identifikatzea, nahiz eta haien artean muga zorrotzak ezartzea ia ezinezkoa den. Egoera batetik muturreko beste batera garamatzan bide horretan zein igarobide dauden, ez da erraza asmatzen.

Aitorren azken pasarte horrek gure gogoeta gidatzen laguntzen digu. Bazterkeria ekonomiko egoeratik 
gizarte bazterkeriara zerk amiltzen gaituen galdetzen diogu gure buruari. Edo alderantziz planteatuz gero, zer ote den pobrezian bizi den pertsona bat gizartean errotuta mantentzen duena.

Gizarte bazterkeria eta ekonomikoaren artean dagoen irudizko jauzi horrek, bizitza ibilbideetan suma daitezkeen haustura uneekin zerikusirik izan dezakeela pentsarazten digu. Hots, zaurgarritasunaren bideetan tartea markatzen dutenak hausturak direla iradokitzera ausartu gintezke.

Haustura hauen aldamenean, zenbait elkarrizketaturen mintzoan frustrazio eta porrot sentimendu arrastoak behatu dira. Bizitza normal bat aurrera eramateko gaitasun eza. Familia aurrera ateratzeko ezintasuna. Estigmatizazioaren zurrunbiloan prozesu indibidual eta kolektiboek egiten dute bat, eta nahasmen horretan kontraesan ugari erna daitezke.

Era paralelo batean, antzerako hausnarketa egin daiteke porrotaren inguruan ere. Porrota egotekotan, argitu beharko litzateke zein punturaino zama dakiokeen norbanakoari eta zein neurritan den gizarteari berari edo administrazio publikoari leporatzeko zerbait. Nolanahi ere, ezin dezakegu pertsona bat bazterkeriara kondenatu hutsegite pertsonal ez kolektiboengatik ere. Zalantzarik gabe, tokian tokiko gobernuen erantzukizuna ere bada neurri handi batean, pobrezia eta bazterkeria bizi duten pertsonak albo batera ez uztea.

Gure protagonista guztiak Diru-sarrerak Bermatzeko Errentaren (DBE) titularrak izan dira, Gizarte bazterkeriaren aurkako borrokaren markoan kokatzen den prestazio ekonomikoaren onuradunak, hain zuzen ere. Prestazio hau jaso ezean galduta leudekeela eman dute aditzera, modu zabalean. Hein handi batean dirulaguntza hau dela haien salbazioa. Kale gorritik, delinkuentzia mundutik, eromenetik edota bere buruaz beste egitetik libratzen dituena.

Aldi berean, esparru ekonomikoan bizi duten zaurgarritasuna helarazi dute. Dituzten baliabide ekonomiko gutxiekin, oinarri-oinarrizko gastuak estaltzeko estualdiak pasa behar dituzte, eta zer esanik ez aparteko gastuak edota ustekabeak suertatzen direnean. Azken batean horrek guztiak segurtasun falta sentimendu handia dakar berekin eta hauskortasun hori gizarte bazterkeriari datxekion alderdi ukaezina da. Edo bestela esanda, gaitasunaren segurtasunaren hutsunearen isla garbia.

Segurtasuna/segurtasun eza eta bakardade sentipenak elkarren eskutik doaz oratuta, izan ere, ziurtasun gabezia eta zaurgarritasuna indargetu baitaitezke ondoan sare bat edukiz gero. Harremanen esparruaz ari gara, familia inguruneaz bereziki. Familia ondoan daukatela jakite hutsak nolabaiteko lasaitasuna ematen dio elkarrizketatu askori. Hau da, egunerokotasunean edota une puntualagoetan familia eremuak eman diezaiekeen laguntzaz gain, nora jo badutela sentitzeak soilik dagoeneko haien hauskortasun egoera leuntzen du.
Puntu honetan saihestezina den funtsezko auzia azaleratzen zaigu: familiarekiko menpekotasunaren eta norbere autonomiaren artean sortzen den barne gatazka, alegia. Prestazioaren baldintza nagusietako bat bizikidetza unitate propioa eratzea exijitzen duena da. Bestela esanda, era independentean eta aparteko etxebizitza batean bizi dela frogatu behar du batek. Zentzu honetan, familiarekiko nolabaiteko autonomia ezartzen da aurrebaldintza gisa.

Prestaziora jo baino, ahal izatekotan familiaren babesera jo lezake batek. Horrelako esaldiak sarri entzuten dira jendartean. Baina, non geratzen da norbanakoak bere autonomia propioa garatzeko izan dezakeen premia eta desioa? Autonomia oinarrizko gaitasuna da, norbere eta giza garapena bermatzeko oinarrizko tresna. Zentzu honetan, a priori behintzat, DBE prestazioa autonomia pertsonala bultza dezakeen neurri gisa ikus genezake.

Landa ikerketan zehar, bestetik, prestazioa jaso arren familiarekiko menpekotasuna bizi duten pertsonekin egin dugu topo. Prestaziotik jasotzen dituzten dirusarrerak ez die denerako ematen eta oinarrizko beharrizan asko ase ahal izateko, era batean edo bestean familiaren sostenguarekin kontatu beharra dute. Segurtasuna eta lasaitasuna ematen dien esparru bera, norbere autonomiaren garatze prozesuan galga bilaka daiteke. Kontraesan anitz sortzen dira testuinguru honetan, norberaren desioek, premiek, mugek eta errealitateek topo egiten duten bidegurutzean.

Pertsonak elkarren artean menpeko gara eta gure menpekotasunei erantzunak emango dizkien zaintza behar dugu. Ez gara esaten ari familia esparruarekiko harremana edota elkarmenpekotasuna desegokia denik, auzia norbere bidea egitea galarazten denean pizten dela baizik. Hartara, Diru-sarrerak Bermatzeko Errentak sorgin gurpil gisa joka dezake. Izan ere, a priori autonomia pertsonalaren pizgarri izan daitekeen prestazio bera, familia esparruarekiko menpekotasunaren indartzaile bilaka baitaiteke. Are gehiago prestazio ekonomiko honek beharrizan materialak eta oinarrizkoenak estaltzeko ere ematen ez duenean eta elkarmenpekotasun afektiboari, menpekotasun ekonomikoa atxikitzen zaionean.

Aldi berean, eta motibo desberdinengatik familia sareak berme eta laguntza hori ematen ez duen kasuetan, hirugarren sektoreko elkarteen rola nabarmendu egiten dela behatu da. Hau da, esparru domestikoak eskaini ezin duen babesgune funtzioa, nolabait elkarte, fundazio eta GKEek betetzen dute zenbait alorretan.

Hasteko prestazioari berari buruzko informazioa eta orientazioa bidera dezakete. Baina hori gutxi balitz, bizikidetza unitate propioaren baldintza bete ahal izateko etxebizitzarako sarbidea errazten egin ohi duten lana ukaezina da. Haien kabuz etxebizitza edo logela bat alokatzeko oztopo larriak lituzketen pertsonek, elkarteek kudeatutako pisu edo egoitzetan topatzen dute aterpea. Behin etxebizitza 'independente' batean bizi direnez geroztik, DBEren eska- 
tzaile izateko ateak irekitzen zaizkie. Kasu honetan, elkarteek emandako laguntza nolabaiteko berme eta lasaitasun izateaz gain, autonomia ekonomikorako bidean akuilu garrantzitsua ere izan daiteke. Esan gabe doa, helduleku hau hil ala bizikoa izan daitekeela kale gorrian egon diren pertsonentzat.

Bistan da hortaz, harremanen eremua -familia- eta hirugarren sektorea -elkarte, fundazio eta GKEakdirela neurri handi batean prestazioaren onuradunen egoera orekatzen duten esparruak. Sostengu horiek ondoan izan eta hortxe daudela jakiteak, ziurgabetasun egoera baretzen du, maila apalean bada ere.

Bi gune hauen absentziak, eta batez ere familia esparru sendo baten gabeziak, zaurgarritasunaren continuum horretan bazterkeriaren intentsitatea biziagotzen dute. Horretaz gain, gizarteko zenbait eremurekin izan daitekeen lotura faltek bazterkeriaren irudi gordinenak erakusten dituzte. Parte hartzerik eza, zaurgarritasunaren funtsezko elementu definitzaileetako bat izanik, isolamendua eta bakardadea continuum horren azken muturren ezaugarri dira.

Senide eta adiskide sareen hutsegitea, lan merkatuan lekurik eza eta espazio publikoetan parte hartze falta dira deserrotze horren irudietako batzuk. Isolamenduaren gaindia, aurreko guztiez gain aisialdiaren absentzia dagoenean gerta daiteke. Aisialdia, Ingrid Robeynsek proposatutako gaitasunen zerrendako elementuetako bat da (2003). Egongo da aisialdia luxua dela uste duenik, baina berebiziko garrantzia du nork bere buruarekin -edo lagunduta- gustuko aktibitateak burutu ahal izateak. Badira gainera kostu ekonomiko txikia edota hutsa duten jarduera ugari, eta horiek praktikatzea arnasbide garrantzitsua izan daiteke.

Robeynsen zerrendaratze horretako beste funtsezko osagai bat errespetua da. Gure kasuan gainera, estigmatizazioarekin lotuta zer pentsatua ekarri digu errespetuaren kontu honek. Estigmatizazioa eta errespetua, biak ere kontzeptu eraikiak dira eta konfiguratze horretan, nork bere buruaz duen irudia eta gizartearen begirada elementu erabakigarriak dira, alde batetik. Bestetik, bakoitzak bere buruari dion errespetua eta gizartetik jaso dezakeena.

Elkarrizketatuen artean pobrezia ekonomikoan bizi diren pertsonak ezagutu ditugu eta baita gizarte bazterkeria egoeran bizi direnak ere. Prestazioak alderdi ekonomikoa hobetzen lagun diezaiekeen arren, landa ikerketak erakutsi digu beronen zenbatekoa motz gelditzen dela oinarrizko gastuak estaltzeko ere. Zentzu askotan bizimodu duin bat izateko minimoez ari gara, autonomia ekonomikoa eta pertsonala landu eta garatu ahal izateko gutxienekoez.

Ildo honetatik, erakundeen eta tokian tokiko gobernuen ardura ere bada, prestazioaren onuradun diren pertsonei errespetua erakustea. Erantzukizun honen izaera ez da familia esparruaren edota hirugarren sektorearen ordezkatzailea izan behar, bere funtzioa ez da izaera ordezkatzailera mugatu behar. Berebi- zikoa da balizko onuradunei a priori eskatzen zaien autonomia hori sustatu eta bermatzea.

Ikerketan zehar erabilitako terminoak gure eginez, gaur egungo krisia DBE politiken ibilbidean haustura edota aukera une gisa uler daiteke, egoerari aurre egiteko aukeratutako neurrien arabera. 2012rako prestazioaren zenbatekoak \% 7an murriztu ziren eta 2011an aurrera eramandako erreformak prestaziora sarbidea izateko baldintzak zorroztu zituen. Besteak beste, erroldatze epea hiru urtera arte luzatzean, heldu berriak diren etorkinak kaltetzen dira zuzenean. Gisa honetako aldaketek, aurrezki ekonomikoa baino berez ahulagoa den kolektibo baten estigmatizazioa biziagotzen dute ${ }^{10}$.

Era berean, azken erreformak lan merkatuan txertatzeko prestutasunari zentraltasun handiagoa eman dio. Baina, prekarietatearen instituzionalizazioaren garaian zer zentzu dauka enpleguari dagoeneko bermatu ezin duen funtzio bat esleitzea? Testuinguru honetan DBE prestazioaren onuradunak lan merkatura lotzerakoan, prekarietatetik eta pobreziak irteteko ahulago geratzeko arriskua handia da.

Gure protagonisten artean lan merkatuarekin harreman zeharo desberdinak dituzten kasuekin egin dugu topo. Zenbaitzuek ageriko oztopoak dituzte enplegu bat aurkitzeko eta enpleguren bat izatekotan, baldintza erabat prekarioetan moldatu beharra dute. Bestetik, begien bistan geratu dira etxeko ardurak eta bereziki haurren zaintza enpleguarekin bateragarri egiteko dauden zailtasunak. Zentzu honetan, esan beharra dago emakumeak izan direla gai honen inguruan gehien hausnartu dutenak, eta aitzitik, guraso diren gizonezkoen artean, bateraezintasun hori baino langabezian egoteak dakarren frustrazioa azpimarratu izan da.

Era paraleloan lan merkatutik kanpoko aktibitateak burutzen dituztenak ere ezagutu ditugu; GKEtan murgilduta dabilen bat, mugimendu politikoetan buru-belarri sartuta dagoen besteren bat, semealabak heztera dedikatu gura duen emakume bat, edota ikasketa osagarriak egiten jarraitu nahi duen beste bat. Zentzu honetan, bene-benetako Hiritartasun Oinarrizko Errenta izan gabe, neurri batean behintzat 'existentziarako eskubidea' garatzea ahalbidetzen duen gutxieneko errenta indartsu gisa joka dezake. Eta ikuspuntu honetatik, DBEk pertsonak 'desmerkantilizatzeko' daukan gaitasuna positiboki baloratzen da.

Abagune honetan gizarte babeserako politikek eta DBEk jokatzen duten papera giltzarri dira. Etorkizunera begira enpleguari egokitu beharreko funtzioa, tentu handiz erabaki beharreko auzia da, gizartearen sektore handi bat pobrezia egoeran bizitzera kondenatu nahi ez bada.

10 2011ko Azaroaren 24an Eusko Legebiltzarrak Gizarteratzeko eta Diru-sarrerak Bermatzeko Legea (abenduaren 23ko 18/2008) aldatu zuen. Kontsultatu, erreformaren aurka gizarte mugimendu eta sindikatuek plazaratutako DBEren erreformaren aurkako manifestua. 
Hein handi batean gaur egun bizi dugun krisia egiturazkoa bada, krisi ekonomikoa heldu aurretik krisi sozial bat ere bazegoelako da. Krisi hau aitzakiatzat hartuz erabakiak norabide batean edo bestean har daitezke, lehentasunen arabera. Defizitak kontrolatzeko agindu inposatuen atzean, ongizate erregimenen zutabe diren hezkuntza eta osasun arloak murrizten ari dira. Kontrako zentzuan, egoeraz baliatzea ere badago Gizarteratzeko Gutxieneko Errenten politikak indartu eta garatzeko ${ }^{11}$.

Orain arte EAEko prestazioa -Nafarroarekin bateraestatuko eskuzabalena izan bada, autogobernuak hala permititu duelako izan da. Eta aukera horretaz baliatu nahi izan delako. Aurrerantzean ere, nahi izanez gero, politika desberdinduak diseinatzeko aukera hori muturreraino profita daiteke.

Batetik, moneta terminoetan prestazioaren zenbatekoa igotzeak gizarte bazterkeriaren esparru ekonomikoan berehalako hobekuntzak ekarriko lituzke, bai arlo materialean eta baita segurtasunaren arloan ere. Gizarte bazterkeriaren konplexutasuna aztertu dugun honetan, argi geratu zaigu esparru ekonomikoa ez dela zaurgarritasuna itxuratzen duen bakarra baina bai, berebiziko garrantzia duela. Latzagoa da egoera prestazioen onuradun gisa ibilbide kronikoagoa duten haientzat. Izan ere zaurgarritasuna behin-behineko izaera izatetik bizitzeko era bilakatzen delako.

Ikerlanean zehar egiaztatu ahal izan dugu pertsona hauen ongizatean hirugarren sektoreak jokatzen duten papera zinez erabakigarria dela. Administrazio publikoak DBEren prestazioaren erabiltzaileak 'zenbaki' gisa hartu ohi dituen bitartean, elkarte eta GKEek aldetik tratua hurbilagoa izan ohi da. Izan ere, 'erabiltzaileekin' baino 'pertsonekin' dihardute.

Hirugarren sektorearen ekarpena bereziki garrantzitsua da familia esparruak huts egiten duen kasuetan edota eremu honek eman dezakeen babesa oso mugatua denean. Honenbestez, gobernu organoek eta gizarteak berak ere sektore honen lana onartu eta aintzatetsi beharra dauka. Ez hori bakarrik, etorkizunera begira ere, esparru hau indartzera bideratutako neurriak sendotzeko beharra planteatu liteke. Arriskua, gobernu eta elkarteen arteko erantzukizunaren banaketan datza: administrazio publikoek bere gain hartu beharreko ardurak ez dizkiote beste inori besterenganatu behar. Bestela esanda, hirugarren sektorearen funtzio osagarria eta ez ordezkagarria sustatu beharra dago.

Azken aldarriak aipatutako errespetuari men egiten dio. Hain zuzen ere, gobernu erakundeei ere badagokie balore honi ziztada ematea, komunikabideetan eta eskola esparruan garatu litezkeen kontzientziazio kanpainen bitartez. Errespetuarekin batera prestazioaren beraren inguruko ezagutza sustatzea funtsezkoa litzateke, izan ere, honezkero egiaztatu dugun moduan, estigmatizazioan eta gizarte bazterkeriaren itxuratzean zeresana duten elementuak baitira biak.

${ }^{11}$ Eusko Jaurlaritzaren Enplegu eta Gizarte gaietako sailak 2012 urte bukaeran argitaratu berri du Pobrezia eta Gizarte Desberdintasunen Inkesta (PGDI). Inkesta honen datuek zenbakitan adierazten dute Gutxieneko Errenten Sistemak gizarteari dakarzkion onurak. DBE, Etxebizitzarako Prestazio Osagarria (EPO) eta Gizarte Larrialdietarako Laguntzak baloratzen diren honetan, sistema honen premia azpimarratzen da. 


\section{Aipatutako bibliografia}

(2011): “4/2011 Dekretua, urtarrilaren 18koa, Gizarte Larrialdietarako Laguntzei buruzkoa", Euskal Herriko Agintaritzaren Aldizkaria, 27. zenb., 2011-2-9 [<http://euskadi.net/bopv2/ datos/2011/02/1100673a.pdf >].

(2011): “4/2011 Legea, azaroaren 24koa, Gizarteratzeko eta Diru Sarrerak Bermatzeko Legea aldatzen duena", Euskal Herriko Agintaritzaren Aldizkaria, 233. zenb., 2011-12-12 [<http://www. lehendakaritza.ejgv.euskadi.net/r48-bopv2/ eu/bopv2/datos/2011/12/1105924e.pdf>].

(2010): "2/2010 Dekretua, urtarrilaren 12koa, etxebizitzako gastuetarako prestazio osagarriari buruzkoa", Euskal Herriko Agintaritzaren Aldizkaria, 11. zenb., 2010-1-19 [khttp://www.euskadi.net/ bopv2/datos/2010/01/1000216a.pdf>].

(2010): “147/2010 Dekretua, maiatzaren 25ekoa, DiruSarrerak Bermatzeko Errentari buruzkoa", Euskal Herriko Agintaritzaren Aldizkaria, 114. zenb., 2010-6-17 [/http://www.euskadi. net/bopv2/datos/2010/06/1003020a.pdf)].

(2009): “Fernando Vidal Fernández: ‘Lo opuesto a la exclusión no es la inclusión, sino la reconciliación"”, [elkarrizketa], Hilero Eguneratuz, 93 zkia., 8-10 or.

(2008): “18/2008 Legea, abenduaren 23koa, Gizarteratzeko eta Diru Sarrerak Bermatzekoa", Euskal Herriko Agintaritzaren Aldizkaria, 250. zenb., 2008-1231, or. 32.729-32.804 [khttp://www.euskadi. net/bopv2/datos/2008/12/0807235a.pdf〉].

ADELANTADO, J. et al. (1999): "Las relaciones entre política social y estructura social”, Revista Internacional de Sociología, 22. zkia., 5-31 or.

DE LA CAL, M. L. (2012): "Realidad y retos de la protección social en Euskadi”, Ekonomiaz, 83. zkia., 256293 or.
ELDER, G.; MORTIMER, J.; eta SHANAHAN, M. (2006): Handbook of the Life Course, Springer, New York.

ELORRIETA, A. (2013): “Zaurgarritasun ibilbideetan balantzaka: Diru-sarrerak Bermatzeko Errentaren argi-ilunak" [doktorego tesia], Euskal Herriko Unibertsitatea, Ekonomia Aplikatua I Departamentua.

ESPING-ANDERSEN, G. (2000): Fundamentos sociales de las economías industriales, Ariel, Bartzelona.

- (1990): Three Worlds of Welfare Capitalism, Cambridge, Polity Press [gaztelaniaz: (1993): Los tres mundos del Estado del bienestar, Valentzia, Edicions Alfons el Magnanim].

EZQUERRA, S. (koord.) (2011): Famílies, exclusió social i disrupcions en els cicles de vida. Una mirada a les polítiques socials des de baix, Bartzelona, Diputació de Barcelona.

GUBRIUM, J.; eta HOLSTEIN, J. (2002): Handbook of Interview Research, Londres, Sage.

HAINBAT EGILE (d.e.): “Joan den irailaren 12an, Eusko Legebiltzarrean aurkeztu zen Gizarteratzeko eta Diru Sarrerak Bermatzeko Legea aldatzeko txostenaren aurrean, sinatzen dugun taldeok honakoa salatu nahi dugu publikoki" [<http:// www.economiasolidaria.org/files/manifestua_ DSB.pdf〉].

KVALE, S. (1996): Interviews: An Introduction to Qualitative Research Interviewing, Sage, Thousand Oaks.

KORPI, W. (2000): "Faces of inequality: Gender, class, and patterns of inequalities in different types of welfare states", Social Politics, 7. bol., 2. zkia., 127-191 or.

LEWIS, J. (2002): "Gender and welfare state change", European Societies, 4. bol., 4. zkia., 331-357 or. 
MORENO FERNÁNDEZ, L. (2003): Bienestar mediterráneo y supermujeres, atala: Documentos de Trabajo, 03-09. zenb., Centro Superior de Investigaciones Científicas, Unidad de Políticas Comparadas [<http://digital.csic.es/ bitstream/10261/1571/1/dt-0309.pdf>].

- (2000): Ciudadanos precarios. La 'última red' de protección social, bilduma: Sociología, Ariel, Bartzelona.

NUSSBAUM, M. (2012): Crear capacidades: propuesta para el desarrollo humano, Paidós, Bartzelona.

- (2003): "Capabilities as fundamental entitlements: Sen and social justice", Feminist Economics, 9. bol., 23. zkia., 2003, 33-59 or.

- (2000): Women and Human Development. The Capabilities Approach, Cambridge University Press, Cambridge.

- (1995): "Human capabilities, female human beings", in NUSSBAUM, M.; eta GLOVER, J., Women, Culture and Development: A Study of Human Capabilities, Clarendon Press, Oxford, 61-104 or.

ORLOFF, A. (1996): “Gender in the welfare state”, Annual Review of Sociology, 22. zkia., 51-78 or.

PÉREZ-OROZCO, A. (2006): “Amenaza tormenta: la crisis de los cuidados y la reorganización del sistema económico", Revista de Economía Crítica, 5. zkia., 7-37 or.

PICCHIO, A. (2003): Unpaid Work and the Economy. A Gender Analysis of the Standards of Living, Routledge, Londres.

PIORE, M. (2006): "Qualitative research, does it fit in economics?”, European Management Review, 3. bol., 1. zkia., 17-23 or.

ROBEYNS, I. (2005): "The capability approach and welfare policies" [konferentzian aurkeztutako papera], Gender Auditing and Gender Budgeting Conference, Bolonia.

- (2003): "Sen's capability approach and gender inequality", Feminist Economics, 9. bol., 23. zkia., 61-92 or.

RUBIN, H.; eta RUBIN, I. (1995): Qualitative Interviewing: The Art of Hearing Data, Sage, Londres.
SEN, A. (1989): "Cooperation, inequality, and the family", Population and Development Review, 15. zkia., 61-76 or.

- (1985): Commodities and Capabilities, Amsterdam, North Holland.

SUBIRATS, J. (zuz.) (2006): Fragilidades vecinas. Narraciones biográficas de exclusión social urbana, Icaria, Bartzelona.

- (zuz.) (2005): Análisis de los factores de exclusión social, saila: Documentos de Trabajo, 6. zenb., Bilbo, Fundación BBVA.

- (zuz.) (2004): "Pobresa i exclusio social. Un analisis de la realitat española i europea", saila: Estudis Socials, 16. zkia., Fundació La Caixa, Bartzelona [<http://obrasocial.lacaixa.es/deployedfiles/ obrasocial/Estaticos/pdf/Estudios_sociales/ vol16_ca.pdf>].

SUBIRATS, J.; ALFAMA, E.; eta OBRADORS, A. (2005): "Ciudadanía e inclusión social frente a las inseguridades contemporáneas. La significación del empleo", in ASTELARRA, J. (koord.), Género y empleo, Madril, Fundación Carolina, 133-138 or [<http://www. fundacioncarolina.es/es-ES/publicaciones/ documentostrabajo/Documents/DT32. pdf\#page=148>].

TAYLOR-GOOBY, P. (1991): “Welfare state regimes and welfare citizenship", Journal of European Social Policy, 1. zkia., 93-105 or.

VALLES, M. S. (2003): Entrevistas cualitativas, saila: Cuadernos Metodológicos, 32. zkia., Madril, Centro de Investigaciones Sociológicas.

VILLALBA, U.; LARRAÑAGA, M.; eta JUBETO, Y. (2011): Tokiko giza garapena eta genero berdintasuna, saila: Lan Koadernoak, 56. zkia., Bilbo, Hegoa; Bilbo, Euskal Herriko Unibertsitatea [«http://publicaciones.hegoa.ehu.es/ assets/pdf2s/264/Hegoa_koadernoak_55. pdf?1317724730〉].

WOLF, J.; eta DE-SHALIT, A. (2007): Disadvantage, New York, Oxford University Press. 